\title{
EFFETCS OF NEW PRODUCT DEVELOPMENT ON PROFITABILITY LEVEL OF THE FIRM: THE CASE OF IGDAŞ
}

\author{
Muzaffer ERTURK \\ IGDAŞ, Turkey
}

\begin{abstract}
The main aim of this study is to investigate the effects of new product development on the competitiveness level of firms by considering the innovations developed by IGDAS (Istanbul Gas Distribution Industry and Trade Incorporated Company). The global competitiveness level of the companies mainly depends on their new product development capability and capacity. Firms' competitiven ess level improves as long as successful new product developments occurs. Main findings of the study prove that new product developments in IGDAŞ decreases costs, increases efficiency, competitiveness and profitability level of the firms.
\end{abstract}

\section{INTRODUCTION}

Companies challenges to survive in a highly competitive ecosystem. A multi-dimensional competition especially from competitors, consumers, fast technological change, economic-social and political changes affects firms deeply. In order to cope with heavy competition, firms want to development new innovative products providing competitive advantage comparing their opponents.

In the global economic conditions, competition level is getting increase for the firms and countries by the time. Firms have to develop new products and innovations in order to survive. Firms developing successful new products and innovations can achieve higher consumer satisfaction, competitive advantage, global competitiveness, market share and profitability.

In this study, we mainly aim to investigate the effects of new product development on the competitiveness level of firms by considering the innovations developed by IIGDAS (Istanbul Gas Distribution Industry and Trade Incorporated Company). As observing the İGDAŞ case, the global competitiveness level of the companies mainly depends on their new product development capability and capacity. For this reason, we can say that firms' competitiveness level improves as long as successful new product developments occurs.

In this respect, first we will analyse the determinants of innovation in the firm level by reviewing the innovation literature and the innovation models. Then, we will investigate the effects of the new product development. Finally we will survey new product development and effects on on the profitability level of the firm to understand the mechanism of new product development. Main contribution of the study will be to prove that successful new product development decreases cost and increases the profitability of firm

\section{DETERMINANTS OF NEW PRODUCT DEVELOPMENT}

By developing new technological innovations, the firms can sustain their competitiveness level in the increasing global competition conditions. For this reason, understanding the determinants of technological innovation and new product development in order to increase competitiveness of the firm is vital for the firms in highly competitive market conditions. On the other hand, there are many internal and external factors in the firm level affecting the technological innovation and new product development for the firms. OECD and EuroStat (2005) stated that "an innovation is the implementation of a new or significantly improved product (good or service), or process, a new marketing method, or a new organisational method in business practices, workplace organisation or external relations. The minimum requirement for an innovation is that the product, process, marketing method or organisational method must be new (or significantly improved) to the firm. This includes products, processes and methods that firms are the first to develop and those that have been adopted from other firms or organisations. Table 1 shows the factors relating to the objectives and effects of innovation". 


\section{Table 1: Factors Relating to the Objectives and Effects of Innovation}

Relevant for:

$\begin{array}{cccc}\text { Process } & \text { Product } & \begin{array}{c}\text { Organisational } \\ \text { innovations }\end{array} & \begin{array}{c}\text { Marketing } \\ \text { innovations }\end{array}\end{array}$

Competition, demand and markets

Replace products being phased out

Increase range of goods and services

Develop environment-friendly products

Increase or maintain market share

Enter new markets

Increase visibility or exposure for products

Reduced time to respond to customer needs

Production and delivery

Improve quality of goods and services

Improve flexibility of production or service

provision

Increase capacity of production or service provision

Reduce unit labour costs

Reduce consumption of materials and energy

Reduce product design costs

Reduce production lead times

Achieve industry technical standards

Reduce operating costs for service provision

Increase efficiency or speed of supplying and/or

delivering goods or services

Improve IT capabilities

Workplace organisation

Improve communication and interaction among

different business activities

Increase sharing or transferring of knowledge with

other organisations

Increase the ability to adapt to different client

demands

Develop stronger relationships with customers

Improve working conditions

Other

Reduce environmental impacts or improve health and safety

Meet regulatory requirements

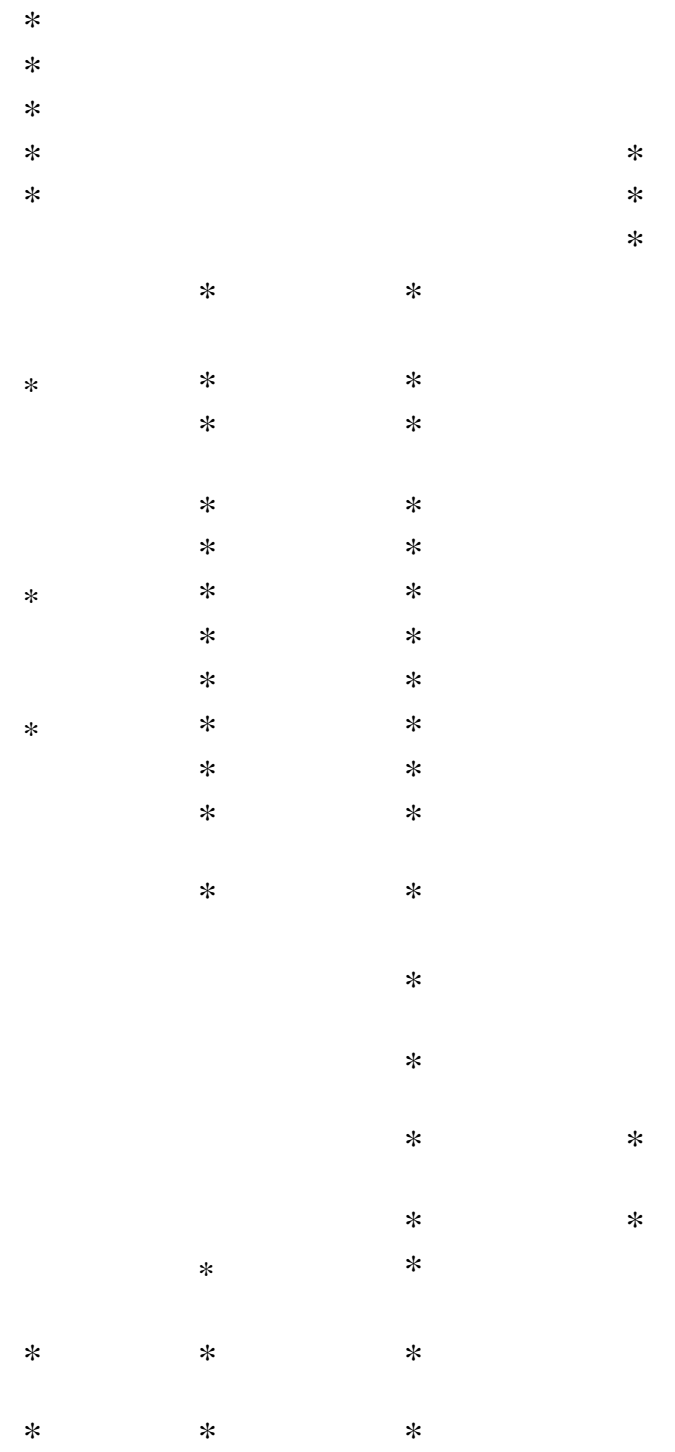

Source: OECD and EUROSTAT (2005), Oslo Manual Guidelines for Collecting and Interpreting Innovation Data, Third Edition, OECD and EUROSTAT Publication, p.108

OECD and EuroStat (2005) stated that four types of innovations can be distinguished: "product innovations, process innovations, marketing innovations and organisational innovations. Product innovations and process innovations are closely related to the concept of technological product innovation and technological process innovation. Marketing innovations and organisational innovations broaden the range of innovations". Table 2 shows the factors hampering innovation activities in the firm level;, cost, knowledge, market, institutional and other factors affect the innovation. 


\begin{tabular}{|c|c|c|c|c|}
\hline & $\begin{array}{l}\text { Process } \\
\text { innovationsi }\end{array}$ & $\begin{array}{l}\text { Product } \\
\text { innovations }\end{array}$ & $\begin{array}{l}\text { Organisational } \\
\text { innovations }\end{array}$ & $\begin{array}{l}\text { Marketing } \\
\text { innovations }\end{array}$ \\
\hline \multicolumn{5}{|l|}{ Cost factors: } \\
\hline Excessive perceived risks & * & $*$ & $*$ & $*$ \\
\hline Cost too high & $*$ & $*$ & $*$ & $*$ \\
\hline Lack of funds within the enterprise & $*$ & $*$ & $*$ & $*$ \\
\hline \multicolumn{5}{|l|}{ Lack of finance from sources outside the enterprise: } \\
\hline Venture capital & $*$ & $*$ & $*$ & $*$ \\
\hline Public sources of funding & * & * & * & * \\
\hline \multicolumn{5}{|l|}{ Knowledge factors: } \\
\hline $\begin{array}{l}\text { Innovation potential (R\&D, design, etc.) } \\
\text { insufficient }\end{array}$ & * & * & & * \\
\hline Lack of qualified personnel: & * & * & & * \\
\hline Within the enterprise & $*$ & * & & * \\
\hline In the labour market & $*$ & $*$ & & $*$ \\
\hline Lack of information on technology & $*$ & $*$ & & $*$ \\
\hline Lack of information on markets & $*$ & * & & $*$ \\
\hline $\begin{array}{l}\text { Deficiencies in the availability of external } \\
\text { services }\end{array}$ & * & * & * & $*$ \\
\hline \multicolumn{5}{|l|}{ Difficulty in finding co-operation partners for: } \\
\hline Product or process development & * & * & & * \\
\hline Marketing partnerships & & & & * \\
\hline \multicolumn{5}{|l|}{ Organisational rigidities within the enterprise: } \\
\hline Attitude of personnel towards change & * & * & $*$ & * \\
\hline Attitude of managers towards change & * & * & $*$ & * \\
\hline Managerial structure of enterprise & $*$ & * & $*$ & * \\
\hline $\begin{array}{l}\text { Inability to devote staff to innovation activity due to } \\
\text { production requirements }\end{array}$ & $*$ & $*$ & & \\
\hline \multicolumn{5}{|l|}{ Market factors: } \\
\hline $\begin{array}{l}\text { Uncertain demand for innovative goods or } \\
\text { services }\end{array}$ & * & & & * \\
\hline Potential market dominated by established enterprises & * & & & $*$ \\
\hline \multicolumn{5}{|l|}{ Institutional factors: } \\
\hline Lack of infrastructure & * & * & & $*$ \\
\hline Weakness of property rights & $*$ & & & $*$ \\
\hline Legislation, regulations, standards, taxation & * & * & & $*$ \\
\hline \multicolumn{5}{|l|}{ Other reasons for not innovating: } \\
\hline No need to innovate due to earlier innovations & * & * & $*$ & $*$ \\
\hline $\begin{array}{l}\text { No need because of lack of demand for } \\
\text { innovations }\end{array}$ & * & & & * \\
\hline
\end{tabular}

Source: OECD and EUROSTAT (2005), Oslo Manual Guidelines for Collecting And Interpreting Innovation Data, Third Edition, OECD and EUROSTAT Publication, p.113

Table 3 shows the relationship between internal factors and innovation in the firm level. Some of the factors have a positive effects and others have a negative effect. 


\section{Table 3: Internal Factors and Innovation}

\begin{tabular}{|c|c|c|}
\hline Factor & Theoretical arguments & Empirical studies \\
\hline \multirow[t]{4}{*}{ Size } & $\begin{array}{l}\text { Large: economies, risk, market, } \\
\text { appropriation }\end{array}$ & $\begin{array}{l}\text { Large: Horowitz (1962), Lunn and Martin (1986), Braga and Willmore } \\
\text { (1991),Henderson and Cockburn (1996), Gumbau (1997), Arundel and } \\
\text { Kabla (1998) }\end{array}$ \\
\hline & $\begin{array}{l}\text { Small: flexibility, } \\
\text { communication, specialisation, } \\
\text { informal controls }\end{array}$ & $\begin{array}{l}\text { Small: Worley (1961), Mansfield (1964), Grabowski (1968), Adams } \\
\text { (1970),Loeb and Lin (1977), Scherer (1984), Acs and Audretsch } \\
\text { (1988), Graves and Langowitz(1993) }\end{array}$ \\
\hline & & $\begin{array}{l}\text { Intermediate: Scherer(1965b), Mansfield et al. (1971), Smith } \\
\text { (1974), Kumar and Saqib (1996) }\end{array}$ \\
\hline & & Both: Rothwell (1986), Pavitt et al. (1987), Rothwell and Dodgson (1994) \\
\hline \multirow[t]{2}{*}{ Debt } & $\begin{array}{l}\text { Negative: specificity, risk, } \\
\text { information asymmetries }\end{array}$ & $\begin{array}{l}\text { Negative: Grabowski (1968), Elliott (1971), Branch (1974), Kamien and } \\
\text { Schwartz (1978), Hall (1990), Long and Ravenscraft (1993), Giudici and } \\
\text { Paleari (2000) }\end{array}$ \\
\hline & & Positive: Scherer (1965a), Lafuente et al. (1985) \\
\hline Human resources & $\begin{array}{l}\text { Positive: qualification, } \\
\text { experience }\end{array}$ & $\begin{array}{l}\text { Positive: Galende and Suarez, } 1998 \text { and Galende and Suarez, } \\
\text { 1999,Martínez-Ros and Salas (1999) }\end{array}$ \\
\hline $\begin{array}{l}\text { Commercial } \\
\text { resources }\end{array}$ & $\begin{array}{l}\text { Positive: reputation, image, } \\
\text { complementary resources, } \\
\text { information }\end{array}$ & $\begin{array}{l}\text { Positive: Freeman (1973), Rothwell et al. (1974), Doi (1985), Lunn and } \\
\text { Martin (1986), Gumbau (1997) }\end{array}$ \\
\hline $\begin{array}{l}\text { Organisational } \\
\text { resources }\end{array}$ & $\begin{array}{l}\text { Positive: co-ordination, } \\
\text { communication, integration, } \\
\text { absorptivecapacity }\end{array}$ & $\begin{array}{l}\text { Positive: Freeman (1973), Rothwell et al. (1974), Rothwell } \\
\text { (1986),Kleinknecht and Reijnen (1992), Busom (1993), Bughin and } \\
\text { Jacques (1994),Kumar and Saqib(1996), Gumbau (1997), Kuemmerle } \\
\text { (1998) }\end{array}$ \\
\hline \multirow[t]{2}{*}{ Diversification } & $\begin{array}{l}\text { Negative: formal and financial } \\
\text { controls }\end{array}$ & Positive: McEachern and Romeo (1978), Link (1982), Chen (1996) \\
\hline & & $\begin{array}{l}\text { Negative: Hoskisson and Hitt (1988), Baysinger and Hoskisson } \\
\text { (1989),Hoskisson and Johnson (1992), Hoskisson et al. (1993) }\end{array}$ \\
\hline Internationalisation & $\begin{array}{l}\text { Positive: competitiveness, } \\
\text { market }\end{array}$ & $\begin{array}{l}\text { Positive: Meisel and Lin (1983), Lunn and Martin (1986), Braga and } \\
\text { Willmore (1991), Busom (1991), Labeaga and Martínez-Ros } \\
\text { (1994), Kumar and Saqib (1996), Galende and Suarez, } 1998 \text { and Galende } \\
\text { and Suarez, 1999) }\end{array}$ \\
\hline
\end{tabular}

Source-: Galende A, Jesús, Juan Manuel De La Fuente, “Internal Factors Determining A Firm’s Innovative Behaviour" Research Policy 32 (2003) 715-736

\section{EFFECTS OF NEW PRODUCT DEVELOPMENT ON THE PROFITABILITY OF THE FIRM}

When we have analysed the mechanism of new product development on the profitability of the firm, we have seen that (as the below figure shows this mechanism), increasing new product development and innovation leads to productivity and product diversification, and decrease in the costs after that increasing competitiveness which results in the increasing profitability of the firm. 


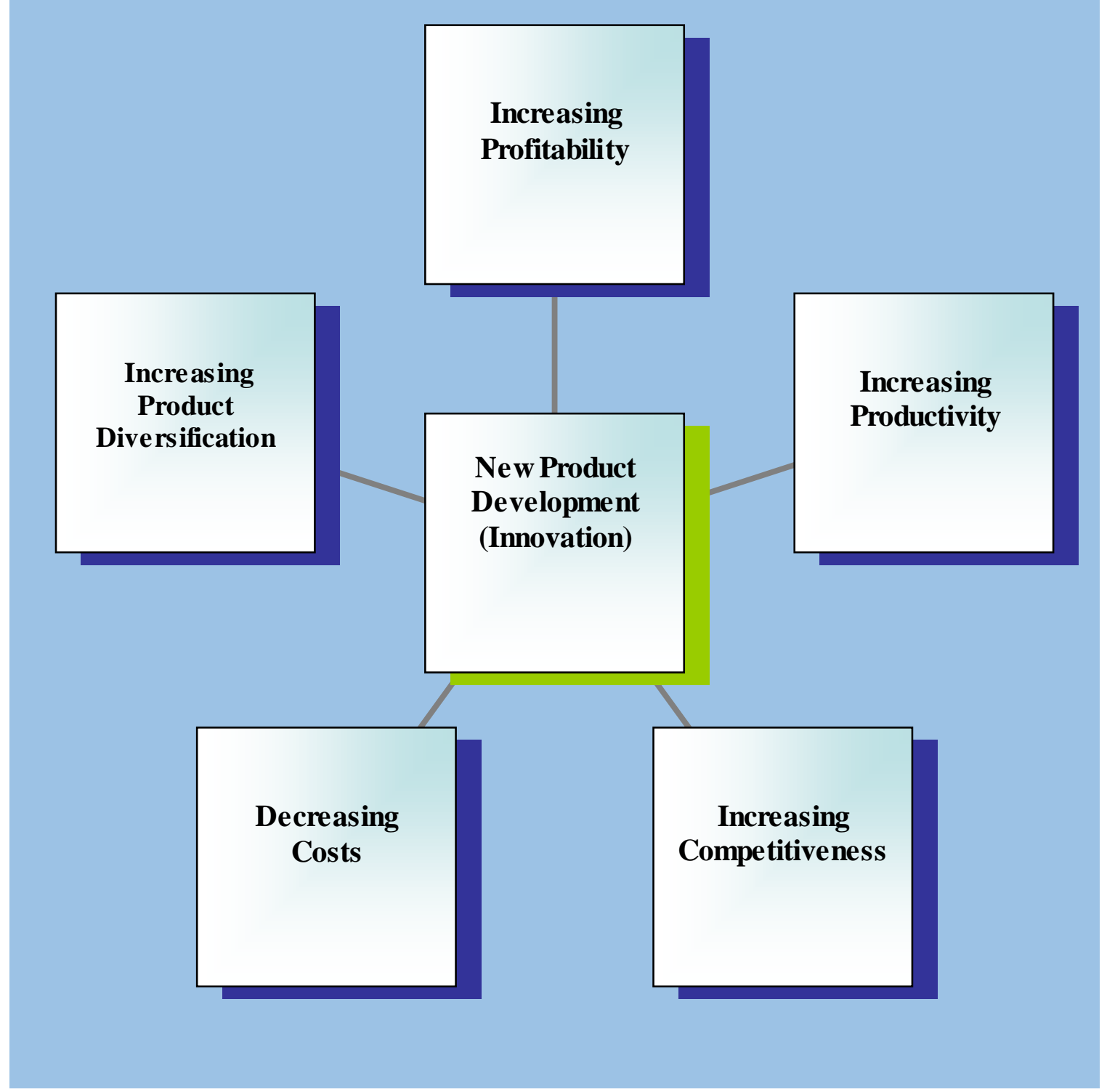

Figure 1: Mechanism of New Product Development on the Profitability of the Firm

Source: Author

Knight (1967) stated that as a result of the rapid advances carried out in science and technology, innovation has become a key concept in today's society. Utterback (1971) argued that technological innovation has an impact on international trade, industry structure, formation and development of new firms and industries, and the growth and the survival of existing firms and industries. Hannay (1980) declared that technological change is one of the most fundamental and powerful forces affecting both the economy and society.

Narayanan (2001: 121) set forth formally that primary objective of technology management should be the creation of value for a firm. Value creation is tied to the competitive advantages that a firm can create in the marketplace or more precisely in the firm's competitive domains.

Huergo and Elena, (2006) proved that the planning and monitoring of the innovation process and the hiring of personnel with special skills for technological activities are significant sources of innovation, although with important differences regarding the type of innovation (process versus product).

Damanpour et al (2009) indicated that a firm's ability to acquire and exploit external knowledge is often critical to achieving and sustaining a competitive advantage. Annavarjula and Mohan (2009) stated that in the 
era of globalisation and with the advent of knowledge economies, organisational innovation has assumed a critical role in enhancing economic performance of firms.

Fariborz et al (2009) showed that the impact of innovation on organizational performance depends on compositions of innovation types over time. Liu et al (2009) stated that the firm's technological-innovationbased strategic capabilities were neither influenced by technological resources, nor by innovation resources, but by organizational culture, human resources and organizational structure, among which human resources are the most dynamic ones ( See also, Betz, 1993; Damanpour et al 2007, 2008; Edquist and Hommen, 1999; Galende et al 2003; Hannay, 1980; Huergo 20066; Knight, 1967; Little, 1981, Narayanan, 2001; Schilling, 2008; Utterback, 1971).

Figure 2 shows essential steps for a successful new services development process. Each step hasto be designed carefully by considering market conditions, consumer preferences and competitors" strategies.

Figure 2: Essential Steps for a Successful New Services Development Process.

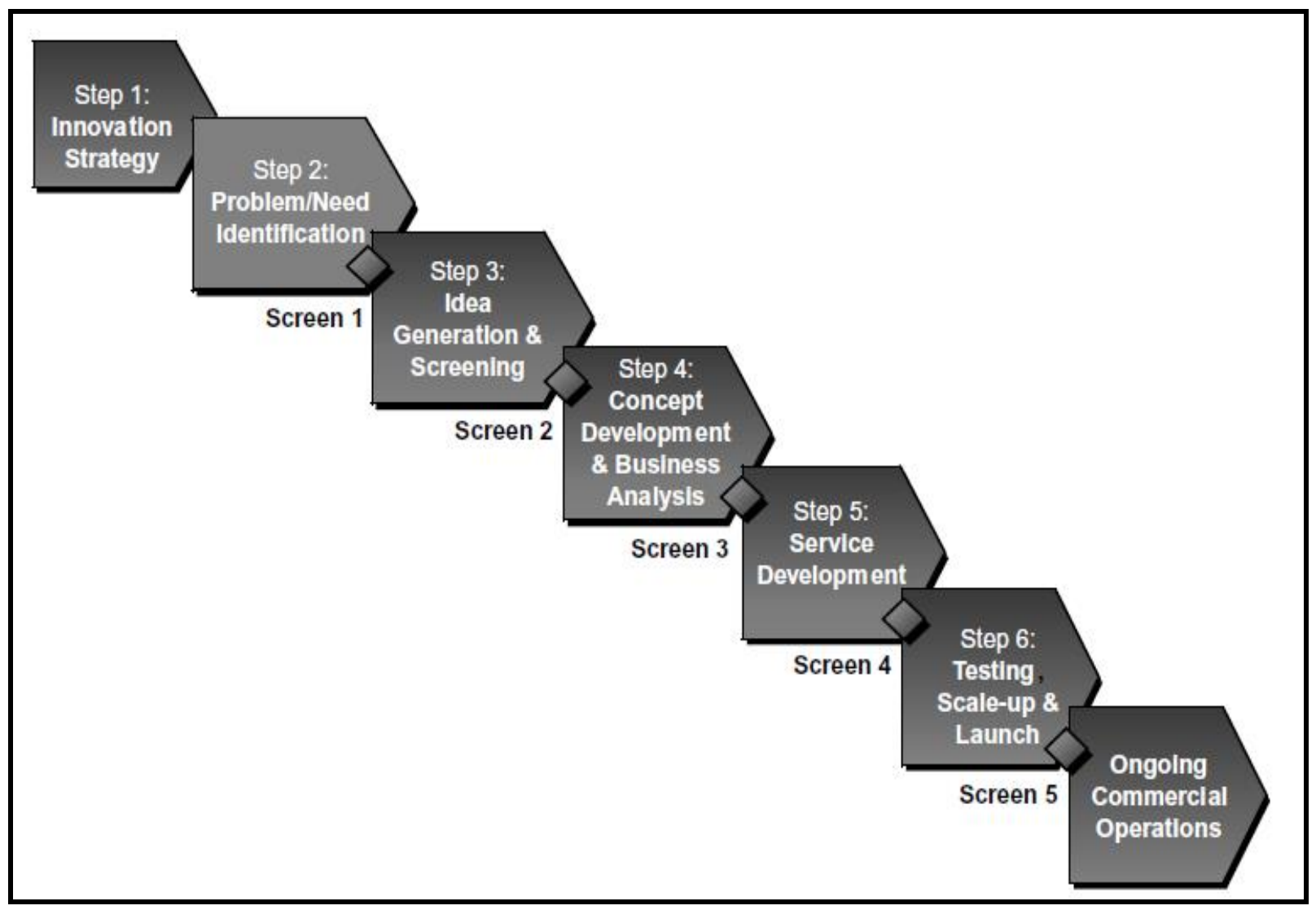

Source: Kuczmarski Thomas D. and Johnston Zachary T., "Service Development", in the PDMA Handbook of New Product Development, Second Edition. Edited by Kenneth B. Kahn, John Wiley \& Sons, -2005, p.92107 


\section{Data, Methodology and Empirical Results}

In order to analyse the new products and innovations on profitability of the firm, we analyse the new products and innovations in IGDAŞ. We mainly focus on a new product service box called IYS-08, on the firms' performance indicators. We collect the data by surveying the firms' managers and practitioners for the effects of IYS-08. The methodology that we have used for this research is the calculation of the density distributions of the firms' managers and practitioners' opinions on the effects of the IYS-08.

Table 4 shows the result of the survey results on managers for the contribution of new product IYS - 08 service box on the firm's performance indicators in İGASS. When we analyse the performance indicators, density distribution of firms' managers and practitioners' opinions are generally concentrated between the ranges of 20-79\%. Rarely outliers are two tails. As a result, we can conclude that, the contribution of new product IYS- 08 service box on the firm's performance indicators in İGDAŞ is very good and at an important level.

Table 4: Survey Results on Managers for the Contribution of New Product IYS-08 Service Box on the Firm's Performance Indicators in İGDAŞ

Table 4: Survey Results on Managers for the Contribution of New Product IYS-08 Service Box on the Firm's Performance Indicators in İGDAŞ

\begin{tabular}{|c|c|c|c|c|c|c|}
\hline & & \multicolumn{5}{|c|}{ (Contribution rate \%) } \\
\hline \multicolumn{2}{|c|}{ Performance Indicators } & $\% 0-19$ & $\% 20-39$ & $\% 40-59$ & $\% 60-79$ & $\% 80-100$ \\
\hline 1 & New Technology Development & & $(\% 25)$ & & $(\% 50)$ & $(\% 25)$ \\
\hline 2 & New Product Development & & & $(\% 50)$ & $(\% 25)$ & $(\% 25)$ \\
\hline 3 & Innovation Rate & & $(\% 25)$ & $(\% 25)$ & $(\% 50)$ & \\
\hline 4 & Costs & & $(\% 25)$ & $(\% 50)$ & $(\% 25)$ & \\
\hline 5 & Productivity & & $(\% 25)$ & $(\% 25)$ & $(\% 50)$ & \\
\hline 6 & Profitability & & $(\% 25)$ & $(\% 25)$ & $(\% 50)$ & \\
\hline 7 & Competitiveness & & $(\% 25)$ & $(\% 25)$ & $(\% 50)$ & \\
\hline 8 & Consumer Satisfaction & & $(\% 25)$ & $(\% 75)$ & $(\% 25)$ & \\
\hline 9 & Employee Satisfaction & $(\% 25)$ & $(\% 25)$ & $(\% 50)$ & & \\
\hline & Market Share in Turkey & $(\% 25)$ & $(\% 25)$ & $(\% 50)$ & & \\
\hline
\end{tabular}

( \% ..) shows density distribution of firms' managers and practitioners' opinions

Source: Author Survey Results,

\section{CONCLUSION}

In highly competitive market conditions, competition level increases for the firms in course of time. Firms have to develop new products and innovations in order to survive. Firms developing successfulnew products and innovations can achieve higher consumer satisfaction, competitive advantage, global competitiveness, market share and profitability. In this study, we have mainly investigated effects of new product development on the competitiveness level of firms by considering the innovations developed by IGDAS.

The global competitiveness level of the companies mainly depends on their new product dev elopment capability and capacity. For this reason, we can say that firms' competitiveness level improves as long as successfulnew product developments occur. As a res ult, we can conclude that, the contribution of new product IYS- 08 service box on the firm's performance indicators in IGDAŞ is very good and at an important level. 


\section{REFERENCES}

Annavarjula, M. And Mohan, R. (2009) "Impact of Technological Innovation Capabilities on the Market Value of Firms." Journal of Information \& Knowledge Management; Vol. 8 Issue 3, pp241-250

Betz, F.(1993) Strategic Technology Management, McGraw-Hill

Damanpour, F., Bierly, Paul E. and Santoro, Michael D. (2009) "The Application of External Knowledge: Organizational Conditions for Exploration and Exploitation" Journal of Management Studies 46:3, 481-509.

Damanpour, Fariborz ,Grevesen, Chris W. (2007) "Performance Implications Of Organisational Structure And Knowledge Sharing In Multinational R\&D Networks." International Journal of Technology Management; Vol. 38;1/2, pp113-136,

Damanpour, Fariborz, Wischnevsky, J. Daniel, (2008) "Radical Strategic and Structural Change: Occurrence, Antecedents and Consequences" International Journal of Technology Management; Vol. 44;1/2, pp53-80,

Edquist, Charles and Leif Hommen, (1999) "Systems of Innovation: Theory and Policy the Demand Side" Technology in Society, 21; 63-79

Fariborz, D.Richard M. W, Claudia N.A. (2009) "Combinative Effects of Innovation Types and Organizational Performance: A Longitudinal Study of Service" Organizations Journal of Management Studies 46:4 June

Galende A, Jesús, Juan Manuel De La Fuente, (2003) "Internal Factors Determining A Firm's Innovative Behaviour" Research Policy 32, 715-736

Hannay, N. Bruce., (1980), "Technological Innovation: Its Nature and Significance" Bulletin of the American Academy of Arts and Sciences, Vol. 33, No. 6, pp34-48

Huergo, Elena. (2006) "The Role of Technological Management as A Source of Innovation: Evidence from Spanish Manufacturing Firms”, Research Policy 35 ;pp1377

Knight, Kenneth E. (1967), "A Descriptive Model of the Intra-Firm Innovation Process", The Journal of Business, Vol. 40; 4. pp. 478-496.

Kuczmarski Thomas D. and Johnston Zachary T., "Service Development", in the PDMA Handbook of New Product Development,Second Edition. Edited by Kenneth B. Kahn, John Wiley \& Sons, 2005, pp.92-107

Little, A.D. The Strategic Management of Technology, 1981, European Management Forum, in Narayanan, V.K. Management Technology and Innovation for Competitive Advantage, Prentice Hal, USA, 2001

Liu, Ju , Baskaran, A. Li, S. (2009) "Building Technological-Innovation-Based Strategic Capabilities at Firm Level in China: A Dynamic Resource-Based-View Case Study." Source: Industry \&Innovation; Vol. 16 Issue 4/5, p411-434

Narayanan, V.K. (2001) Management Technology and Innovation for Competitive Advantage, Prentice Hal, USA

OECD And Eurostat, (2005) Oslo Manual Guidelines for Collecting and Interpreting Innovation Data, Third Edition, A Joint Publication Of OECD And Eurostat

Schilling, M. A., (2008) Strategic Management of Technological Innovation, McGraw-Hill, Irvin, USA, 2008 ,

Utterback, James M. (1971),"The Process of Technological Innovation within the Firm” The Academy of Management Journal, Vol. 14 ,1pp. 75-88 